九州大学学術情報リポジトリ

Kyushu University Institutional Repository

\title{
Respiration Rate and Quality of Spinach Cultivated in Night-cooling Greenhouse in Summer
}

Hu, Wenzhong

Deaprtment of Bioengineering, Dalian Nationalities University

Tanaka, Shun-ichiro

Deaprtment of Bioengineering, Dalian Nationalities University

Genkawa, Takuma

Laboratory of Postharvest Science, Division of Bioproduction System Science, Department of Bioproduction Environmental Sciences, Graduate School of Bioresoruce and Bioenvironmental Sciences, Kyushu University

Hori, Yoshiaki

Laboratory of Postharvest Science, Division of Bioproduction System Science, Department of Bioproduction Environmental Sciences, Faculty of Agriculture Kyushu University

https://doi.org/10.5109/4602

出版情報：九州大学大学院農学研究院紀要. 49 (2)，pp.409-417，2004-10-01. Faculty of Agriculture, Kyushu University

バージョン :

権利関係: 


\title{
Respiration Rate and Quality of Spinach Cultivated in Night-cooling Greenhouse in Summer
}

\author{
Wenzhong HU', Shun-ichiro TANAKA*, Takuma GENKAWA ${ }^{2}$ \\ and Yoshiaki HORI
}
Laboratory of Postharvest Science, Division of Bioproduction System Science, Department of Bioproduction Environmental Sciences, Faculty of Agriculture Kyushu University, Fukuoka 812-8581, Japan
(Received June 22, 2004 and accepted July 13, 2004)

\begin{abstract}
Respiration rate of spinach (Spinacia oleracea L.) cultivated in night-cooling greenhouse were measured and the changes in quality attributes were also determined during growth of spinach in summer. The result showed that there was lower level of respiration rate in night-cooling greenhouse than that in control, indicating that respiration rate was suppressed markedly in night-cooling greenhouse at night. The increase in the leaf length and area of spinach in night-cooling greenhouse was also much larger than that of control. Significant differences in height and leaf area $(p<0.01)$ were found between spinach planted in night-cooling greenhouse and control. It was also shown that there were significant differences $(p<0.05)$ in $\mathrm{SPAD}$ as a chlorophyll index and ascorbic acid content at harvest period. These results suggested that higher quality of spinach could be obtained from night-cooling greenhouse in summer.
\end{abstract}

\section{INTRODUCTION}

Plant growth is limited by the environment which is less than ideal it will become a limiting factor in plant growth. Most plant problems are caused by environmental stress, either directly or indirectly (Hans and Peter, 1992). Therefore, it is important to understand the environmental aspects that affect plant development and growth. Plants are grown within a controlled environment so that. One of the main tasks in greenhouse construction is to optimize the conditions for plant developments involving photosynthesis and respiration, generally during the off-season from normal outside field production. The greenhouse as a controlled environment agriculture (CEA) allows horticultural practices to be optimized and an increased variety of crops to be produced at the impropriate environmental conditions of higher or lower temperatures. It effectively improves the environment in greenhouse and enables plants suited to the climates condition to be successfully grown. The greenhouse regulates the temperature, relative humidity (RH), and $\mathrm{CO}_{2}$ concentration of the atmosphere inside. The vegetables are also grown in the greenhouse at different seasons of the year, especially for that the vegetables cannot be grown outdoors in summer climate.

1 Department of Bioengineering, Dalian Nationalities University, Dalian 116600, Peoples R China

${ }^{2}$ Laboratory of Postharvest Science, Division of Bioproduction System Science, Department of Bioproduction Environmental Sciences, Graduate School of Bioresource and Bioenvironmental Sciences, Kyushu University

* Corresponding author (E-mail: stanaka@bpes.kyushu-u.ac.jp) 
Spinach is one of the most important vegetables in Japan. But one factor of high temperature limits spinach production in summer (Kagawa, 1999). It is practiced less during the summer as the hot condition often lead to spinach growth irregularly and death (Tanaka et al., 1993). Because spinach is classified as a hardy cool season crop (Toledo et al., 2003). It is not suitable to grow under the environment of higher temperature, especially in summer. Ishibashi et al. (1978) and Tanaka et al. (1993) reported that better growth and quality of spinach cultivated were obtained in night-cooling greenhouse at temperature of $15^{\circ} \mathrm{C}$ by the refrigeration system in summer. But in control (cultivated in field), growth of spinach was irregular and most of them died due to higher temperature. However, little information of respiration rate and quality of spinach cultivated in night-cooling greenhouse was reported. The objectives of this work were to clarify the effects of lower night temperature on the respiration and quality of spinach sowed in greenhouse and develop new technique of high quality spinach production to meet the demand of consumer in summer. The changes in quality attributes were also determined during growth of spinach.

\section{MATERIALS AND METHODS}

\section{Growing conditions}

Spinaches (Spinacia oleracea L. cv Active) were sowed in pots ( $15 \mathrm{~cm}$ in diameter) containing a mixture of soil, peat, and sand (1:1:1). The pots were spaced $10 \mathrm{~cm}$ apart and were divided into two groups. One group (treatment) of spinach was grown under night temperature conditions of $15^{\circ} \mathrm{C}$ from $\mathrm{PM} \mathrm{6:00} \mathrm{to} \mathrm{AM}$ 8:00 by refrigerator (200R-CLTA, Hitachi, Japan). Other group (control) of spinach was grown in greenhouse under normal condition. Spinach was fertilized with soluble liquid fertilizer (OK-F-1, Otuska Ltd, Japan) every 3 to $4 \mathrm{~d}$ during growth. Air and soil temperatures in greenhouse were measured by an aspirated type- $\mathrm{T}$ (copper-constantan) thermocouple at $1.5 \mathrm{~m}$ above ground and $5 \mathrm{~cm}$ below ground in the pot, respectively.

\section{Respiration rate}

Respiration rate was determined by using a respiratory system at $15^{\circ} \mathrm{C}$ for treatment and $25-27^{\circ} \mathrm{C}$ for control. The five pots of each treatment with growing spinach were randomly sampled and placed in respiratory room (diameter: $50 \mathrm{~cm}$, height: $60 \mathrm{~cm}$ ) and sealed. The fresh air that $\mathrm{CO}_{2}$ in air was absorbed by $20 \% \mathrm{NaOH}$ was flow through the room for $2 \mathrm{~h}$. The well-distributed gas was obtained by fan in the room. When the gas concentration was stable inside, measurement was started. Gas samples in inlet, outlet were withdrawn by gas-tight $1.0 \mathrm{ml}$ syringe. The gas concentrations were measured by injecting $1.0 \mathrm{ml}$ gas sample into gas chromatography (GL Sciences GC-390, Tokyo Japan) equipped with thermal conductivity detector (TCD) and D2000 integrator (Hitachi, Ltd. Tokyo Japan). Helium was used as carrier gas and the flow rate was $30 \mathrm{ml} \cdot \mathrm{min}^{-1}$. The injector and column temperatures were 80 and $50^{\circ} \mathrm{C}$, respectively. The respiration rate of spinach was calculated from following equations. 


$$
R R=\frac{\left(\mathrm{CO}_{2}\right) \text { out }-\left(\mathrm{CO}_{2}\right) \text { in }}{10^{6}} \times F \times \frac{273}{273+T} \times \frac{44}{22.4} \times \frac{1000}{M}
$$

Where $R R$ : respiration rate (mg $\left.\mathrm{CO}_{2} \mathrm{~kg}^{-1} \mathrm{~h}^{-1}\right) ; \mathrm{CO}_{2}$ in: $\mathrm{CO}_{2}$ concentration in inlet of chamber $\left(\mu \mathrm{ll}^{-1}\right) ; \mathrm{CO}_{2}$ out: $\mathrm{CO}_{2}$ concentration in exit of chamber $\left(\mu \mathrm{ll}^{-1}\right) ; F$ : flow rate of fresh air $\left(\mathrm{ml} \mathrm{h}^{-1}\right) ; T$ : temperature of chamber $\left({ }^{\circ} \mathrm{C}\right) ; M$ : mass of sample spinach $(\mathrm{kg})$.

\section{Ascorbic acid content}

Ascorbic acid content was measured by high performance liquid chromatography (HPLC) equipped with Shim-pack SCR-101N column $(7.9 \mathrm{~mm} \phi \times 30 \mathrm{~cm})$ (Shimadzu Corp., Tokyo Japan). The column is packed with a cation exchanger resin which is sulfonated polystylene-divinylbenzene copolymer. The mobile phase was mixed solution of $10 \mathrm{mM}$ oxalic acid dihydrate, $15 \mathrm{mM} \mathrm{NaOH}$ and $1 \mathrm{mM}$ EDTA at a flow rate of $1.0 \mathrm{ml} \mathrm{min}^{-1}$. Temperature is $40^{\circ} \mathrm{C}$ and detector is RI. Spinach sample was extracted from excised slices of $5 \mathrm{~g}$ spinach with 5 times the volume of $5 \%$ metaphosphoric acid in a mortar with pestle. The homogenate was filtered through filter paper and centrifuged at 3,000 rpm for $15 \mathrm{~min}$. The supernatant was taken as sample to measure the ascorbic acid content in spinach.

\section{Dry matter}

Dry matter was measured during growth. The condition of measurement was under $105^{\circ} \mathrm{C}$ for $24 \mathrm{~h}$. Dry matter was determined and expressed as the percentage with respect to the initial fresh weight.

\section{Leaf area}

Leaf area was measured by weight method. The ratio of area and weight of copied graph paper was calculated. And then each leaf of spinach was placed on print paper, and then size and shape of spinach were drawn in the paper. The paper was copied, and then drew section was cut and weighed. The leaf area was determined based on the ratio from the result of measured weight of drew section of print paper. The area of spinach was calculated from following equations.

$$
A_{L}=\frac{A}{M_{1}} \times M_{2}
$$

Where $A_{L}$ : area of spinach $\left(\mathrm{cm}^{2}\right) ; A$ : area of print paper $\left(\mathrm{cm}^{2}\right) ; M_{1}:$ mass of print paper $(\mathrm{g})$; $M_{2}$ : mass of copied drew section of print paper (g)

\section{Chlorophyll index}

The leaf color of spinach was determined by chlorophyll meter (Minolta, SPAD-502) during growth. Measurement was carried on 2 parts of each leaf. The value of SPAD was correlation with chlorophyll content as a chlorophyll index. 


\section{RESULTS AND DISCUSSION}

\section{Respiration rate}

Changes in respiration rate of spinach in greenhouse during growth were shown in Fig. 1. Respiration rates were lower in night-cooling greenhouse than that of control at night during growth. In initial period, respiration rate increased gradually from 10.5 to $50.1 \mathrm{mg} \mathrm{kg}^{-1} \mathrm{~h}^{-1}$ and then decreased to $6.9 \mathrm{mg} \mathrm{kg}^{-1} \mathrm{~h}^{-1}$ at night-cooling greenhouse. For control, respiration rate increased and then decreased to $90.3 \mathrm{mg} \mathrm{kg}^{-1} \mathrm{~h}^{-1}$ after $8 \mathrm{~d}$. And then increased sharply to $242.0 \mathrm{mg} \mathrm{kg}^{-1} \mathrm{~h}^{-1}$ and decreased to $110.0 \mathrm{mg} \mathrm{kg}^{-1} \mathrm{~h}^{-1}$. It showed that there was lower level of respiration rate in night-cooling greenhouse than that in control. Respiration rate was suppressed markedly in night-cooling greenhouse. It has been reported that respiration increases with temperatures increasing until temperature gets too high, then respiration decreases due to tissue deterioration and denatures proteins (unfolding of proteins). The environmental conditions can produce a stress on plants resulting in lower yields. In such cases the environment can be artificially modified, such as in greenhouses, to meet the crop requirements.

Each kind of crop grows and develops most rapidly at a favorable range of air temperatures. This is called the optimum air temperature range. For most crops the optimum functional efficiency occurs mostly between 12 and $24^{\circ} \mathrm{C}$. Most crops (especially vegetables) can be classified according to the temperature requirements of their optimum air temperature range. However, they are generally grouped into whether they require low or high air temperatures for growth. Temperature requirements are usually based on night temperature. Those that grow and develop below $18^{\circ} \mathrm{C}$ are the cool season crops, which originated in temperate climates usually require low temperature.

High temperature results in increase rates of most biochemical functions within the plant, including respiration and enzymatic processes involved in growth. The plant gives

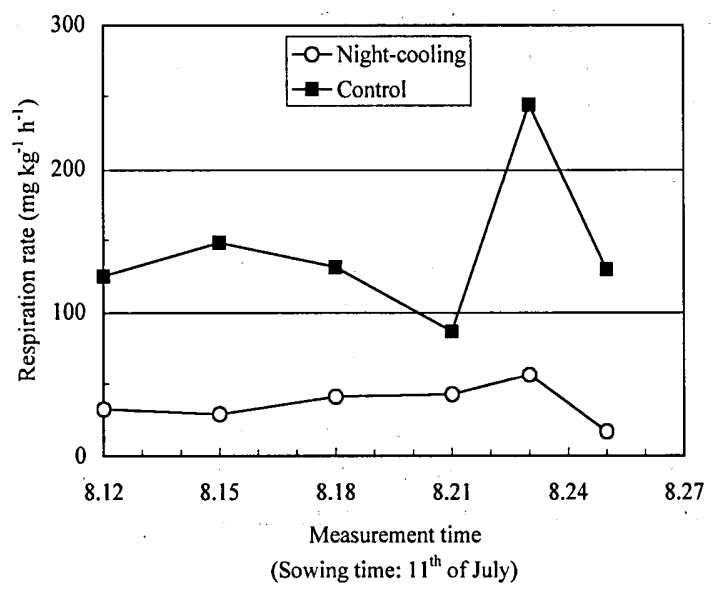

Fig. 1. Changes in respiration rate of spinach during growth in greenhouse. 
off some $\mathrm{CO}_{2}$ during respiration but it needs more for photosynthesis. Photosynthesis produces organic compounds from inorganic carbon by using the energy of sunlight (Massacci et al., 1995). Above $35^{\circ} \mathrm{C}$, the photosynthetic rate levels off, whereas the respiratory rate continues to increase linearly. Consequently, around $35^{\circ} \mathrm{C}$ growth ceases as net carbohydrate consumption through respiration exceeds net carbohydrate fixation through photosynthesis. In general, rates of biochemical processes slow down as the temperature drops. The energy stored in this sugar is released as ATP (adenosine triphosphate) during cellular respiration. At that high temperature the amount of glucose consumed exceeds the amount produced thereby ceasing growth. In this experiment, cultivated spinach is a kind of cool season crops, which usually require low temperature for development and growth.

\section{Leaf length and area of spinach}

Changes in the leaf length of spinach during growth were shown in Fig. 2. There was trend of increase in length of leaf during growth. In night-cooling greenhouse, increase in length of leaf was much larger than that of control. The similar result was also found in the changes in area of leaf during growth (Fig. 3). It showed that there was much higher value in night-cooling greenhouse than that of control. It indicated that night temperature affected the productivity and growth of spinach. If temperatures are high and day length is long, cool-season crops such as spinach will bolt rather than be in progress of desired growth. Adverse temperatures also cause stunted growth and poor quality. Temperature allows the plant to photosynthesize and respire during an optimum daytime temperature and to curtail the rate of respiration during a cooler night (Loreto et al., 1994). This means that the products of photosynthesis are being stored much more than they are being used. For growth to occur, photosynthesis must be greater than respira-

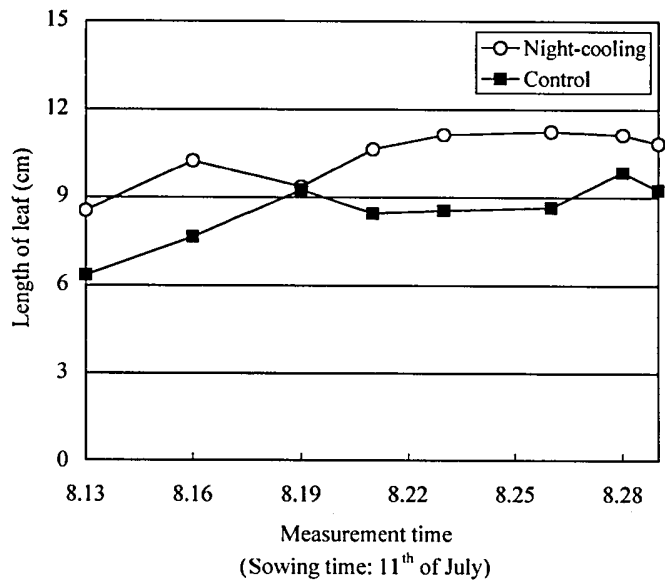

Fig. 2. Changes in the length spinach leaf during growth in greenhouse. 


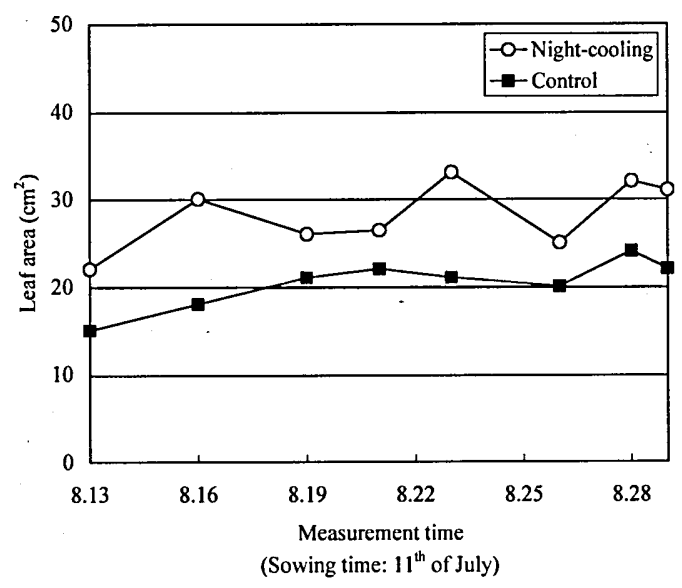

Fig. 3. Changes in leaf area of spinach during growth in greenhouse.

tion. Not all plants grow best in the same temperature range. For example, snapdragons grow best when nighttime temperatures are $12^{\circ} \mathrm{C}$; the poinsettia prefers $17^{\circ} \mathrm{C}$. Recently it has been found that roses can tolerate much lower nighttime temperatures than was previously believed. This has meant conservation in energy for greenhouse growers. However, in some cases a certain number of days of low temperatures are needed by plants to grow properly. The high temperature also takes placed increases in transpiration and results in wilt of spinach, and low temperatures reduce energy use and increase sugar storage during active growth.

\section{SPAD green color}

Changes in SPAD of spinach during growth were shown in Fig. 4. The value of SPAD was correlation with chlorophyll content as a chlorophyll index. In the night-cooling greenhouse, the value of SPAD was lower than that of control. But it showed that value of SPAD continued to increase until harvest and there was higher value of SPAD in the near harvest time. It was considered that biosynthesis of chlorophyll was slightly inhibited initial period of night-cooling greenhouse and then increased gradually. While in control, it showed the similar trend of increase in initial period, and decreased with increase in night temperature in summer. The production time is a bit longer and some reactions of biosynthesis of chlorophyll were carried out at suitable night temperature (Porra et al., 1989). The spinach has a bit larger, deeper green leaves at initial period for control.

\section{Ascorbic acid content}

Changes in ascorbic acid of spinach during growth were showed in Fig. 5. In initial 


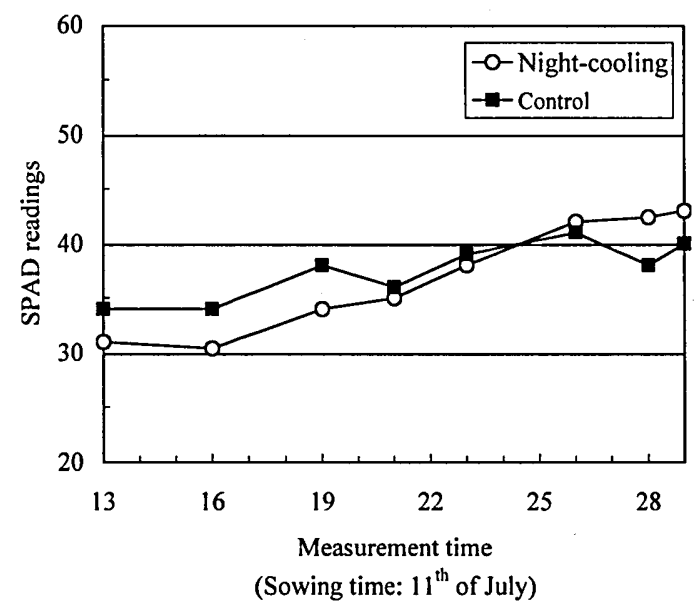

Fig. 4. Changes in SPAD of spinach during growth in greenhouse.

period, it showed the similar trend of increase, and then increased quickly for night-cooling greenhouse. While in control, ascorbic acid content decreased quickly and then increased, but the content was lower than that of treatment. It was considered that ascorbic acid in night-cooling greenhouse was oxidized less than control due mainly to inhibiting respiratory metabolism at lower night temperature. It indicated that higher quality of spinach could be obtained from cultivation in night-cooling greenhouse.

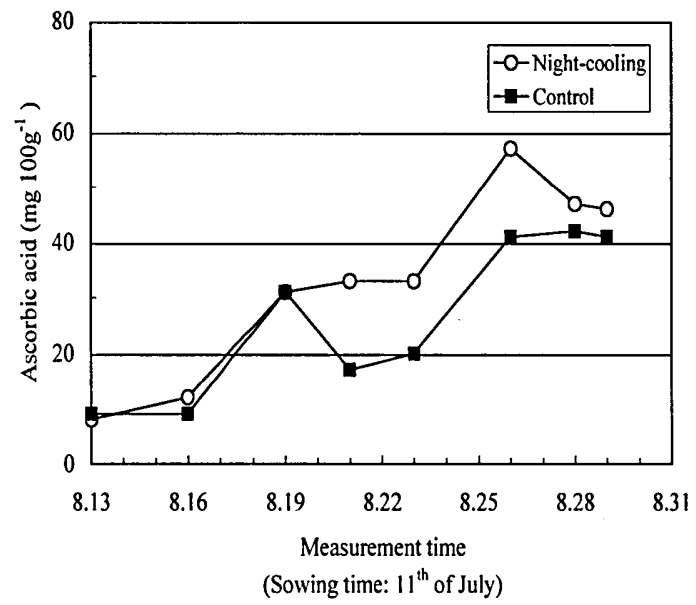

Fig. 5. Changes in ascorbic acid of spinach during growth in greenhouse. 


\section{Qualities of harvested spinach}

The qualities of harvested spinach were shown in Table 1. Height and leaf area of harvested spinach were $23.2 \mathrm{~cm}$ and $406 \mathrm{~cm}^{2}$, higher than that of control. Significant differences in height and leaf area $(p<0.01)$ were found between spinach planted in night-cooling greenhouse and control. It was also shown that there were significant differences $(p<0.05)$ in SPAD and ascorbic acid content as quality index. But values of leaf count and fresh weight in night-cooling greenhouse were lower than that of control. These results indicated that higher quality of spinach could be obtained from night-cooling greenhouse with large leaf area, deep green color and high ascorbic acid content in summer.

Table 1. Qualities of harvested spinach.

\begin{tabular}{lcc}
\hline Items of measurement & Night-cooling & Control \\
\hline Height of spinach (cm) & 23.2 & $19.3^{* *}$ \\
Leaf area $\left(\mathrm{cm}^{2}\right)$ & 406.2 & $354.3^{* *}$ \\
Leaf count (N) & 14.0 & 16.0 \\
Fresh weight (g) & 21.1 & 21.2 \\
Leaf/leaf stalk & 2.3 & $2.0^{* *}$ \\
SPAD & 42.0 & $39.8^{*}$ \\
Ascorbic acid (mg $\left.100 \mathrm{~g}^{-1}\right)$ & 45.8 & $36.8^{*}$ \\
\hline ** Significant differences between night-cooling and control value $(p<0.01)$ \\
$*$ Significant differences between night-cooling and control value $(p<0.05)$
\end{tabular}

\section{CONCLUSIONS}

The study shows that spinach can be grown successfully as a kind of cool season leafy vegetable in summer. Respiration rate was greatly reduced under night-cooling environmental condition in greenhouse. The higher values of leaf length and area of spinach in night-cooling greenhouse were obtained during growth and the relative higher value of SPAD as a chlorophyll index and ascorbic acid content were also achieved at harvest period. It was suggested that spinach could be cultivated in night-cooling greenhouse and better quality of spinach can be obtained in summer.

\section{REFERENCES}

Hans, M. and S. Peter 1992 Plant physiology. Spriger, pp. 534-538

Hu, W., S. Tanaka, T. Uchino, T. Nakamura, T. Kawawaki, D. Hamanaka and Y. Hori 2003 Effect of initial low oxygen concentration on respiration and quality of fresh-cut cabbages. J. Fac. Agr. Kyushu Univ., 47: 195-207

Ishinashi, S., S. Tanaka and K. Mori 1978 Development of the greenhouse growing-system with cooling and heating facility using geothermal energy (I) -Vegetables growing by means of night cooling in summer-. Joumal of the Japanese Soc. Agri. Machinery, 40(2): 207-214 (in Japanese)

Kagawa, A. 1999 Cultivation physiology of high quality spinach, Ishizue, pp. 21-38 (in Japanese)

Loreto, F., D. G. Marco, D. Tricoli and T. D. Sharkey 1994 Measurements of mesophyll conductance, 
photosynthetic electron transport and alternative electron sinks of field grown wheat leaves. Photosynth Res., 41: 397-403

Massacci, A., M. A. Iannelli, F. Pietrini and F. Loreto 1995 The effect of growth at low temperature on photosynthetic characteristics and mechanisms of photoprotection of maize leaves. $J$ Exp Bot., 46: 119-127

Porra, R. J., W. A. Thompson and P. E. Kriedemann 1989 Determination of accurate extinction coefficients and simultaneous equations for assaying chlorophyll a and $\mathrm{b}$ extracted with four different solvents: verification of the concentration of chlorophyll standards by atomic absorption spectroscopy. Biochim Biophys Acta. 975: 384-394

Tanaka, S., S. Ishinashi and M. Kaieda 1993 Design and development of a greenhouse growing system with a cooling facility using geothermal energy. Heat Transfer-Japanese Research, 22: 340-354

Toledo, M. E. A., Y. Ueda, Y. Imahori and M. Ayaki $2003 \mathrm{~L}$-ascorbic acid metabolism in spinach (Spinacia oleracea L.) during postharvest storage in light and dark, Postharvest Biol. And Technol., 28: 47-57 